\title{
PENINGKATAN KEMAMPUAN MEMBACA PEMAHAMAN MELALUI STRATEGI PEMBELAJARAN DIRECTED READING THINKING ACTIVITY (DRTA) SISWA KELAS V-B SDN 24 KENDARI
}

\author{
Jusmaniar $^{1)}$, La Rabani ${ }^{1)}$, Mansyur $\mathbf{M}^{1)}$ \\ ${ }^{1)}$ Jurusan Pendidikan Guru Sekolah Dasar \\ FKIP Universitas Halu Oleo \\ Email: jusmaniar090@gmail.com, larabani59@gmail.com, mansyurm919@gmail.com
}

\begin{abstract}
Abstrak: Penelitian ini bertujuan untuk meningkatkan kemampuan membaca pemahaman siswa kelas V-B melalui strategi Directed Reading Thinking Activity (DRTA) di SD Negeri 24 Kendari. Prosedur penelitian ini yaitu: (a) perencanaan (planning), (b) pelaksanaan tindakan (action), (c) observasi dan evaluasi (observation and evaluation), dan (d) refleksi (reflection). Jenis data yaitu data kualitatif dan data kuantitatif. Data kualitatif diperoleh melalui lembar observasi sedangkan data kualitatif melalui tes hasil belajar. Hasil analisis penelitian pada siklus I terdapat 17 siswa yang telah mencapai nilai $\geq 75$ dengan ketuntasan sebesar $68 \%$, dan terdapat 8 orang siswa atau $32 \%$ yang tidak tuntas, dan nilai rata-rata yang diperoleh siswa tersebut adalah 73,14 . Siklus II terdapat 21 siswa telah mencapai nilai $\geq 75$ dengan ketuntasan sebesar $84 \%$, dan terdapat 4 orang siswa atau $16 \%$ yang tidak tuntas, dan nilai rata-rata yang diperoleh siswa tersebut adalah 86,46.
\end{abstract}

Kata kunci: Kemampuan membaca pemahaman; Strategi Directed Reading Thinking Activity (DRTA)

\section{IMPROVING UNDERSTANDING READING ABILITY THROUGH DIRECTED READING THINKING LEARNING STRATEGIESACTIVITY (DRTA) STUDENTS OF V-B CLASS SDN 24 KENDARI}

\begin{abstract}
This research aims to improve students' reading comprehension skills in the V-B class through the Directed Reading Thinking Activity (DRTA) strategy at SD Negeri 24 Kendari. The procedures of this research are: (a) planning (planning), (b) implementing actions, (c) observation and evaluation (observation and evaluation), and (d) reflection. The types of data are qualitative data and quantitative data. Qualitative data obtained through observation sheets while qualitative data through learning outcomes tests. The results of the analysis of research in the first cycle 17 students had achieved a value of $\geq 75$ with completeness of $68 \%$, and there were 8 students or $32 \%$ who were incomplete, and the average value obtained by these students was 73.14. Cycle II, 21 students have achieved grades $\geq 75$ with completeness of $84 \%$, and there are 4 students or $16 \%$ who are incomplete, and the average value obtained by these students is 86.46 .
\end{abstract}

Keywords: Reading comprehension ability; Strategy Directed Reading Thinking Activity (DRTA) 


\section{Pendahuluan}

Bahasa Indonesia merupakan bahasa yang mempunyai peran penting di dalam berkomunikasi baik secara lisan maupun tulisan. Bahasa Indonesia merupakan bahasa resmi Republik Indonesia yang dijadikan sebagai bahasa pengantar dalam kegiatan pembelajaran di sekolah. Bahasa Indonesia bahkan dijadikan salah satu mata pelajaran wajib dan tolak ukur kelulusan peserta didik di lembaga pendidikan tidak terkecuali di Sekolah Dasar. Menurut Harijatiwidjaja (2017, p. 64) keterampilan berbahasa mencakup empat keterampilan, yaitu keterampilan menyimak, keterampilan berbicara, keterampilan membaca, dan keterampilan menulis. Keempat keterampilan berbahasa itu dalam praktiknya tidak dapat dipisahkan karena satu dengan yang lain saling berhubungan.

Salah satu keterampilan berbahasa yang harus dikuasai siswa adalah keterampilan membaca. Menurut Klein, dkk dalam Rahim (2009, p. 3) mengemukakan bahwa definisi membaca mencakup (1) membaca merupakan suatu proses, (2) membaca adalah strategis, dan (3) membaca merupakan interaktif. Membaca merupakan suatu proses dimaksudkan informasi dari teks dan pengetahuan yang dimiliki oleh pembaca mempunyai peranan yang utama dalam membentuk makna. Membaca juga merupakan suatu strategis. Pembaca yang efektif menggunakan berbagai strategi membaca yang sesuai dengan teks dan konteks dalam rangka mengkonstruk makna ketika membaca. Membaca adalah interaktif. Keterlibatan pembaca dengan teks tergantung pada konteks. Orang yang senang membaca suatu teks yang bermanfaat, akan menemui beberapa tujuan yang ingin dicapainya, teks yang dibaca seseorang harus mudah dipahami (readable) sehingga terjadi interaksi antara pembaca dan teks.

Farr dalam Puspitasari (2015, p. 2) mengemukakan "reading is the heart of education" yang artinya membaca merupakan jantung pendidikan. Dalam hal ini, orang yang sering membaca, pendidikannya akan maju dan ia akan memiliki wawasan yang luas. Jadi, tidaklah berlebihan jika pengajaran membaca perlu mendapatkan posisi yang sangat penting karena dengan membaca kita dapat mengakses informasi-informasi yang berguna, menambah wawasan, dan pengetahuan baru yang semakin meningkatkan kecerdasan sehingga siswa lebih mampu menjawab tantangan yang akan datang.

Kegiatan membaca yang dibelajarkan pada jenjang Sekolah Dasar memiliki beberapa jenis. Pembelajaran membaca di Sekolah Dasar dapat digolongkan menjadi dua, yaitu membaca permulaan untuk kelas I, II dan membaca lanjut untuk kelas III - VI. Membaca permulaan bertujuan untuk menyuarakan kalimat yang ditulis dengan intonasi yang benar. Sedangkan membaca lanjut bertujuan agar siswa mengambil manfaat, memahami isi, dan menyerap pikiran atau perasaan orang lain melalui tulisan serta pesan yang disampaikan penulis melalui bacaan. Membaca lanjut disebut juga dengan membaca pemahaman. Kegiatan membaca pemahaman merupakan suatu kegiatan yang bertujuan untuk mendapatkan informasi yang mendalam serta pemahaman tentang apa yang dibaca.

Dewasa ini, siswa dihadapkan pada kesulitan untuk memahami suatu bacaan secara efektif dan rendahnya minat baca pada anak-anak di Indonesia, sehingga berimbas pada rendahnya mutu atau sumber daya masyarakat, kualitas pendidikan, dan sumber daya manusianya sendiri (Harefa, Sukma, \& Desyandri, 2019, p. 436). Hal yang paling dasar terlihat adalah pada rendahnya hasil belajar siswa. Pada siswa sekolah dasar khususnya kelas atas (kelas IV-VI), permasalahan literasi yang sering terjadi adalah mengenai keterampilan membaca pemahaman. Masih banyak peserta didik yang belum bisa memahami isi bacaan. Sebagian besar siswa dapat dengan lancar membaca suatu teks bacaan, namun hanya sedikit yang mampu memahami maksud atau isi dari teks yang mereka baca. Sehingga berdampak pada rendahnya hasil belajar siswa.

Peranan guru dalam proses pembentukan kemampuan membaca siswa antara lain menciptakan pengalaman yang memperkenalkan, memelihara, atau memperluas kemampuan siswa untuk memahami isi teks. Hal ini mempersyaratkan guru harus melaksanakan pembelajaran langsung, memodelkan, membantu meningkatkan, memfasilitasi siswa dan mengikut sertakan dalam pembelajaran (Farida dalam Murti, 2019, p. 182).

Permasalahan yang terjadi dalam pembelajaran Bahasa Indonesia khususnya pada aspek membaca penting untuk guru perhatikan di kelas. Karena, ketika seseorang mengalami 
permasalahan dalam keterampilan membacanya maka hampir dapat dipastikan seseorang tersebut tidak akan mampu memahami bacaan ataupun teks yang telah dibaca (Ningrum, 2013, p. 2). Selain itu, kegagalan dalam pembelajaran membaca pada mata pelajaran Bahasa Indonesia secara langsung maupun tidak langsung, akan mempengaruhi ketidakberhasilan dalam mata pelajaran lain. Karena sejatinya, kegiatan membaca tidak hanya digunakan dalam mata pelajaran Bahasa Indonesia, namun juga digunakan dalam mata pelajaran lain sebagai sarana memahami materi maupun memahami soal. Menurut Wiryodijoyo dalam Fatih (2019, p. 28) membaca pemahaman merupakan kemampuan menerjemahkan kata-kata penulis sehingga menimbulkan pemikiranpemikiran atau ide-ide yang berguna bagi pembaca, seperti yang terkandung dalam bacaan.

Permasalahan dalam pembelajaran membaca pemahaman juga terjadi di kelas V-B SDN 24 Kendari. Berdasarkan hasil observasi awal yang dilaksanakan pada Jumat, 25 Oktober 2019 diketahui bahwa kemampuan siswa di dalam memahami isi bacaan masih sangat rendah, sehingga berdampak pada rendahnya hasil belajar siswa. Data hasil belajar siswa kelas V-B Tahun Ajaran 2018/2019 pada Tema 7 Peristiwa dalam Kehidupan menunjukkan bahwa dari jumlah 25 orang siswa terdapat 16 orang (64\%) siswa yang belum tuntas dengan rata-rata klasikal sebesar 67,93. Salah satu faktor yang menjadi penyebab masalah tersebut adalah kemampuan siswa di dalam memahami isi bacaan yang masih sangat rendah.

Berdasarkan hasil observasi awal yang dilakukan oleh peneliti di SD Negeri 24 Kendari, juga ditemukan permasalahan dari aspek guru dalam hal pembelajaran dan strategi yang digunakan seperti: (1) guru kurang menunjukkan cara belajar yang bermakna bagi siswa, hal tersebut terlihat dari pembelajaran yang biasa dilakukan guru dengan memerintahkan siswa membuka buku lalu membacanya (2) guru kurang menggunakan strategi yang bervariasi, terlihat dari strategi pembelajaran yang digunakan guru masih konvensional atau biasa saja dengan mencatat materi yang ada di buku kemudian menjawab pertanyaan.

Dari hasil temuan tersebut maka perlu dirancang suatu strategi pembelajaran yang dapat menarik perhatian siswa dalam hal membaca dan kemampuan membaca pemahaman dengan menggunakan strategi Directed Reading Thinking Activity (DRTA).

Strategi membaca dan berpikir secara langsung atau DRTA (Directed Reading Thinking Activity) adalah strategi yang melatih siswa untuk berkonsentrasi guna memahami isi bacaan secara serius. Strategi DRTA adalah strategi membaca yang melibatkan siswa berpikir tentang bacaan memfokuskan keterlibatan siswa dengan teks, karena siswa memprediksi dan membuktikannya ketika mereka membaca. Strategi ini sangat cocok diterapkan dalam kegiatan membaca karena strategi ini bertujuan untuk melatih siswa berkonsentrasi dan berpikir keras guna memahami isi bacaan secara serius (Aningsih, Jayanti, 2017, p. 24). Selain itu, Jainiyah (2015, p. 2) juga mengemukakan bahwa strategi DRTA diarahkan untuk mencapai tujuan umum, yaitu guru mengamati anak-anak ketika mereka membaca dalam rangka mendiagnosis kesulitan dan menawarkan bantuan ketika siswa sulit berinteraksi dengan bahan bacaan.

Rahim (2009, p. 52) menjelaskan bahwa kelebihan strategi Directed Reading Thinking Activity (DRTA): (1) dapat meningkatkan kemampuan pemahaman siswa dalam memahami suatu teks atau cerita; (2) strategi DRTA merupakan suatu aktivitas pemahaman yang meramalkan cerita hingga dapat membantu siswa untuk memperoleh gambaran keseluruhan dari suatu materi yang sudah dibacanya; (3) dapat membuat siswa berfikir tentang apa yang telah diketahui tentang sesuai topic; (4) strategi DRTA dapat menarik minat siswa untuk belajar, karena dalam strategi DRTA menggunakan berbagai metode yang tidak hanya melayani siswa secara audio-visual, tetapi juga kinestesis; (5) strategi DRTA menunjukkan cara belajar yang bermakna bagi siswa, sebab belajar bukan hanya untuk belajar akan tetapi mempersiapkan untuk hidup selanjutnya.

Secara khusus DRTA bertujuan untuk mengembangkan kemampuan siswa dalam (1) menjelaskan tujuan membaca; (2) mengutip, memahami, dan mengasimilasikan informasi; (3) membahas bahan bacaan berdasarkan tujuan membaca; (4) menggantungkan keputusan, dan; (5) membuat keputusan berdasarkan informasi yang diperoleh dari kegiatan membaca (Apriliana, 2018, p. 73).

Berdasarkan uraian di atas, penulis ingin menindak lanjuti dengan melakukan penelitian berjudul "Peningkatan kemampuan membaca pemahaman melalui strategi Directed Reading Thinking Activity (DRTA) siswa kelas V-B SDN 24 Kendari." 
Penelitian yang relevan dengan penelitian ini adalah penelitian yang dilakukan oleh Dilla Puspitasari dengan judul "Peningkatan Kemampuan Membaca Pemahaman Cerita Pendek Melalui Penerapan Strategi Directed Reading Thinking Activity (DRTA) Pada Siswa Kelas V SD Negeri I Rabak kabupaten Purbalingga." Hasil penelitian menunjukan strategi DRTA dapat meningkatkan kemampuan siswa dalam membaca pemahaman pada mata pelajaran bahasa Indonesia. Hal tersebut dapat dibuktikan dengan peningkatan persentase keaktifan siswa $61,47 \%$ dengan kriteria cukup pada siklus I kemudian pada siklus II naik menjadi 75,68\% dengan kriteria baik. Adanya peningkatan ketuntasan hasil belajar siswa dapat dilihat pada siklus I ke siklus II. Persentase siklus I adalah $72,7 \%$ sedangkan persentase siklus II adalah $100 \%$.

Masalah dalam penelitian ini adalah "apakah strategi Directed Reading Thinking Activity (DRTA) dapat meningkatkan kemampuan membaca pemahaman siswa kelas V-B di SD Negeri 24 Kendari?"

\section{Metode Penelitian}

Jenis penelitian yang digunakan dalam penelitian ini adalah penelitian tindakan kelas (PTK). Penelitian ini dilaksanakan di kelas V-B SD Negeri 24 Kendari yang beralamat di Jln. Poros Gunung Jati, Lorong Damai, Kelurahan Gunung Jati, Kecamatan Kendari, Kota Kendari, pada semester genap Tahun Ajaran 2019/2020. Subjek penelitian ini adalah guru dan siswa kelas V-B SD Negeri 24 Kendari yang berjumlah 25 orang siswa yang terdiri dari 11 orang siswa laki-laki dan 14 orang siswa perempuan. Faktor yang diteliti dalam penelitian ini adalah 1) faktor guru, berupa aktivitas mengajar guru di dalam kelas; 2) faktor siswa, berupa aktivitas belajar siswa di dalam kelas dan hasil belajar siswa. Penelitian tindakan kelas ini dilaksanakan dalam 2 (dua) siklus.

Adapun prosedur penelitian tindakan ini sesuai dengan pendapat Arikunto, dkk (2015, p. 152-153) meliputi: (1) Perencanaan (planning), (2) PelaksanaanTindakan (action), (3) Observasi dan Evaluasi (observation and evaluation, dan (4) Refleksi (reflection). Jenis data yaitu data kualitatif dan data kuantitatif. Data kualitatif diperoleh melalui observasi menggunakan lembar observasi sedangkan data kuantitatif diperoleh melalui tes setiap akhir siklus tindakan. Analisis data yang digunakan dalam penelitian ini terbagi dua yaitu analisis kualitatif dan analisis kuantitatif. Data kualitatif akan dianalisis secara deskriptif kualitatif berdasarkan hasil observasi yang dilakukan. Sedangkan data kuantitatif dianalisis secara kuantitatif berdasarkan hasil tes pada setiap akhir siklus tindakan.

1. Persentase ketuntasan secara klasikal yang diperoleh perbandingan dengan kriteria rentangan

sebagai berikut:

$$
\mathbf{P}=\frac{\mathrm{N}}{\mathrm{n}} \times 100 \%
$$

Keterangan:

$\mathrm{P}=$ persentase ketuntasan klasikal

$\mathrm{N}=$ jumlah siswa yang tuntas belajar

$\mathrm{n}=$ jumlah seluruh siswa

(Indarti, 2008:26)

2. Nilai hasil ketuntasan individu

$$
\mathrm{N}=\frac{\text { skor yang diperoleh }}{\text { skor maksimal }} \times 100
$$

Keterangan: Tuntas Jika siswa mendapat nilai $\geq 75$

(Indarti, 2008:26)

3. Nilai rata-rata hasil tes

$$
\mathbf{X}=\frac{\text { jumlah data }}{\text { banyaknya data }}
$$




\section{Hasil Penelitian}

\section{Aktivitas Mengajar Guru}

Aktivitas mengajar guru yang diamati dalam penelitian ini adalah bagaimana cara guru dalam mengaplikasikan langkah-langkah dari strategi Directed Reading Thinking Activity (DRTA) dalam proses pembelajaran. Dari hasil pengamatan observer yang diperoleh melalui lembar observasi tindakan siklus I pertemuan 1 menunjukkan bahwa ada beberapa hal yang tidak dilakukan guru dalam proses pembelajaran dengan penerapan strategi Directed Reading Thinking Activity (DRTA) diantaranya adalah: pada tahap awal guru tidak menginformasikan tahapan kegiatan pembelajaran yang akan dilakukan sehingga siswa tidak mengetahui bahwa proses pembelajaran akan dilaksanakan menggunakan strategi Directed Reading Thinking Activity (DRTA). Pada kegiatan inti di tahap prabaca, pada saat guru menuliskan judul bacaan di papan tulis sebagian besar siswa masih gaduh, dan ketika guru bertanya kepada siswa tentang prediksi mereka mengenai isi bacaan berdasarkan judul yang ditulis, siswa masih kebingungan sehingga siswa masih ragu-ragu untuk menjawab pertanyaan dari guru. Setelah itu guru langsung mengintruksikan siswa untuk menuliskan prediksi mereka pada lembar kerja dan membagikan materi atau buku siswa sehingga kegiatan memandu diskusi siswa dalam memprediksi isi bacaan berdasarkan judul tidak terlaksana.

Pada tahap membaca guru tidak memerintahkan siswa untuk membaca paragraf pertama dari bacaan. Guru langsung memberikan intruksi kepada siswa untuk membaca secara keseluruhan isi teks, guru tidak meminta siswa untuk menilai ketepatan prediksi yang telah mereka tulis dengan informasi penting yang mereka dapatkan dari teks bacaan. Pada tahap pascabaca guru tidak menjelaskan terlebih dahulu isi dari teks bacaan. Guru langsung mengintruksikan siswa untuk menjawab pertanyaan terkait dengan teks. Hal tersebut membuat siswa masih kebingungan atau kurang memahami materi.

Berdasarkan hasil observasi yang dilakukan peneliti pada siklus II, proses kegiatan belajar mengajar yang terjadi di dalam kelas sudah banyak perubahan daripada pertemuan yang sebelumnya. Setelah melakukan seluruh rangkaian kegiatan pendahuluan, guru melanjutkan pembelajaran dengan membagi siswa ke dalam beberapa kelompok dan membagikan LKS yang telah disiapkan. Bersama dengan teman kelompoknya siswa dibimbing untuk memprediksi isi cerita berdasarkan judul yang telah ditulis di papan tulis. Tak lupa guru memberikan beberapa pertanyaan yang dapat memancing prediksi siswa berdasarkan judul.

Pada tahap membaca, guru meminta siswa untuk membaca paragraf pertama dari teks yang terdapat dalam buku siswa kemudian memprediksi isi dari keseluruhan teks bacaan berdasarkan paragraf pertama tersebut. Seluruh prediksi yang telah dibuat ditulis dalam bagian dari lembar kerja yang disediakan. Guru kemudian memerintahkan siswa untuk membaca keseluruhan isi teks dan menuliskan informasi penting yang mereka dapatkan dari teks bacaan. Sebelumnya guru telah menjelaskan apa itu informasi penting dan informasi penting yang akan ditulis menggunakan aspek $5 \mathrm{~W}+1 \mathrm{H}$. Guru melanjutkan kegiatan dengan meminta siswa untuk menilai ketepatan prediksi yang mereka buat dengan informasi penting yang mereka dapatkan.

Pada tahap pacsabaca, guru menjelaskan materi yang berkaitan dengan teks bacaan dan meminta siswa untuk menyelesaikan permasalahan yang terdapat dalam LKS. Setelah selesai, setiap perwakilan kelompok menyampaikan hasil dari diskusinya. Pada siklus kedua ini guru terlihat telah menguasai langkah-langkah dari strategi pembelajaran Directed Reading Thinking Activity (DRTA). Adapun rekapitulasi hasil observasi aktivitas mengajar guru dapat dilihat pada tabel di bawah ini. 
Tabel 1. Rekapitulasi Aktivitas Mengajar Guru siklus I dan Siklus II

\begin{tabular}{llcccc}
\hline \multirow{2}{*}{ No. } & Aspek yang diamati & \multicolumn{2}{c}{ Siklus I } & \multicolumn{2}{c}{ Siklus II } \\
\cline { 2 - 6 } & & Pert. 1 & Pert. 2 & Pert. 1 & Pert. 2 \\
\hline 1. & Pendahuluan & 2 & 1 & 2 & 3 \\
\hline 2. & Kegiatan Inti & 2 & & & \\
& - Tahap Prabaca & 3 & 3 & 3 \\
$\quad$ - Tahap Membaca & 3 & 5 & 6 & 6 \\
$\quad$ - Tahap Pascabaca & 1 & 1 & 2 & 2 \\
\hline 3. Penutup & 1 & 1 & 1 & 2 \\
\hline Jumlah & $\mathbf{9}$ & $\mathbf{1 1}$ & $\mathbf{1 4}$ & $\mathbf{1 6}$ \\
\hline Persentase (\%) & $\mathbf{5 6}$ & $\mathbf{6 9}$ & $\mathbf{8 8}$ & $\mathbf{1 0 0}$ \\
\hline Rata-rata & & $\mathbf{1 0}$ & & & $\mathbf{1 5}$ \\
\hline
\end{tabular}

Sumber: Diolah dari lembar observasi aktivitas guru

Berdasarkan tabel 1 di atas, menunjukkan bahwa pada siklus I pertemuan 1 skor yang diperoleh pada aktivitas mengajar guru sebanyak 9 dengan persentase sebesar $56 \%$ dan pada pertemuan 2 sebanyak 11 dengan persentase $69 \%$. Sementara pada siklus II pertemuan 1 skor yang diperoleh sebanyak 14 dengan persentase keterlaksanaan sebesar $88 \%$ dan pada pertemuan 2 sebanyak 16 dengan persentase keterlaksanaan sebesar $100 \%$.

\section{Aktivitas Belajar Siswa}

Aktivitas belajar siswa yang diamati dalam penelitian ini adalah bagaimana sikap siswa dalam proses pembelajaran ketika guru mengaplikasikan langkah-langkah dari strategi Directed Reading Thinking Activity (DRTA). Hasil observasi aktivitas siswa dalam pembelajaran pada siklus I (satu) menunjukkan bahwa sebagian besar siswa belum mampu menemukan informasi penting, menentukan ide pokok, dan masih sulit untuk membuat prediksi.

Setelah observasi siklus II, aktivitas siswa dalam pembelajaran mengalami peningkatan. Siswa terlihat lebih antusias dalam menjawab pertanyaan yang diberikan oleh guru sehingga mereka lebih aktif dalam memprediksi isi bacaan berdasarkan pengetahuan dan pengalaman yang mereka ketahui mengenai teks bacaan. Setelah melakukan prediksi ini siswa terlihat lebih aktif dalam membaca karena mereka terdorong untuk membuktikan prediksi yang telah mereka buat dengan isi dari bacaan yang sesungguhnya. Adapun rekapitulasi hasil observasi aktivitas belajar siswa dapat dilihat pada tabel di bawah ini.

Tabel 2. Rekapitulasi Aktivitas Belajar siswa siklus I dan Siklus II

\begin{tabular}{|c|c|c|c|c|c|}
\hline \multirow[t]{2}{*}{ No. } & \multirow[t]{2}{*}{ Aspek yang diamati } & \multicolumn{2}{|c|}{ Siklus I } & \multicolumn{2}{|c|}{ Siklus II } \\
\hline & & Pert. 1 & Pert. 2 & Pert. 1 & Pert. 2 \\
\hline 1. & Pendahuluan & 2 & 1 & 2 & 3 \\
\hline \multirow[t]{4}{*}{2.} & Kegiatan Inti & & & & \\
\hline & - Tahap Prabaca & 2 & 3 & 3 & 3 \\
\hline & - Tahap Membaca & 3 & 5 & 6 & 6 \\
\hline & - Tahap Pascabaca & 1 & 1 & 2 & 2 \\
\hline & Penutup & 1 & 1 & 1 & 2 \\
\hline \multicolumn{2}{|c|}{ Jumlah } & 9 & 11 & 14 & 16 \\
\hline \multicolumn{2}{|c|}{ Persentase (\%) } & 56 & 69 & 88 & 100 \\
\hline \multicolumn{2}{|c|}{ Rata-rata } & \multicolumn{2}{|c|}{10} & \multicolumn{2}{|c|}{15} \\
\hline
\end{tabular}

Sumber: Diolah dari lembar observasi aktivitas belajar siswa

Berdasarkan tabel 1 di atas, menunjukkan bahwa pada siklus I pertemuan 1 skor yang diperoleh pada aktivitas belajar siswa sebanyak 9 dengan persentase sebesar $56 \%$ dan pada pertemuan 2 sebanyak 11 dengan persentase $69 \%$. Sementara pada siklus II pertemuan 1 skor yang diperoleh sebanyak 14 dengan persentase keterlaksanaan sebesar $88 \%$ dan pada pertemuan 2 sebanyak 16 dengan persentase keterlaksanaan sebesar $100 \%$. 


\section{Hasil Belajar (Kemampuan membaca pemahaman)}

Hasil analisis penelitian pada kemampuan membaca pemahaman siswa siklus I terdapat 17 siswa yang telah mencapai nilai $\geq 75$ dengan ketuntasan sebesar $68 \%$ dan 8 orang siswa atau $32 \%$ yang tidak tuntas dan nilai rata-rata yang diperoleh siswa tersebut adalah 73,14 . Siklus II terdapat 21 siswa telah mencapai nilai $\geq 75$ dengan ketuntasan sebesar $84 \%$. Dan 4 orang siswa $16 \%$ yang tidak tuntas dan nilai rata-rata yang diperoleh siswa tersebut adalah 86,46.

Tabel 3. Daftar Hasil Belajar Siswa Siklus I dan Siklus II

\begin{tabular}{ccc}
\hline Pencapaian & Siklus I & Siklus II \\
\hline Jumlah siswa & 25 Orang & 25 Orang \\
\hline Nilai Tertinggi & 92,85 & 96,15 \\
\hline Nilai Terendah & 35,71 & 57,69 \\
\hline Nilai Rata-rata & 73,14 & 86,46 \\
\hline \% Tuntas & $68 \%$ & $84 \%$ \\
\hline \% Tidak tuntas & $32 \%$ & $16 \%$
\end{tabular}

Sumber: Diolah dari data hasil penelitian

Berdasarkan tabel di atas, menunjukan bahwa kemampuan membaca pemahaman siswa kelas V-B pada tema Peristiwa dalam Kehidupan mengalami peningkatan yang sangat signifikan dengan kategori sangat baik.

\section{Pembahasan}

\section{Aktivitas mengajar guru}

Aktivitas mengajar guru pada penelitian ini diketahui melalui hasil observasi pada setiap siklus tindakan di setiap pembelajaran. Berdasarkan hasil penelitian yang telah dipaparkan dapat dikatakan bahwa aktivitas mengajar guru pada siklus I sudah baik, namun masih terdapat beberapa kelemahan-kelemahan sehingga berdampak pada hasil belajar (kemampuan membaca pemahaman siswa) yang belum mencapai indikator keberhasilan yang telah ditetapkan. Kelemahan-kelemahan yang terjadi pada siklus I dijadikan sebagai salah satu unsur utama dalam pelaksanaan tindakan siklus II.

Pada kegiatan pembelajaran siklus II guru terlihat lebih memotivasi siswa pada tahap prabaca dengan memberikan pertanyaan-pertanyaan tentang pengalaman sehari-hari yang berkaitan dengan topik sehingga menambah wawasan siswa dalam memahami bacaan. Kegiatan bertanya pada tahap prabaca dimaksud untuk menjembatani antara pengalaman dan pengetahuan yang telah dimiliki siswa dengan apa yang tertulis dalam teks dalam rangka memperoleh pemahaman. Hal ini sesuai dengan pendapat Burns dalam Murti (2019, p. 189) bahwa pengalaman latar merupakan hal penting untuk keberhasilan membaca. Sebab, siswa harus mengenal konsep-konsep dan kosakata dalam bentuk tertulis untuk memperoleh pemahaman. Selain itu, guru juga lebih mengaktifkan dan membimbing siswa dalam memprediksi isi dari bacaan, baik prediksi berdasarkan judul maupun prediksi setelah membaca paragraf pertama dari bacaan. Tindakan guru yang memberikan pemantapan materi setelah pembelajaran pada tahap pasca baca, serta mendiskusikan pertanyaan yang belum terjawab dapat meningkatkan pemahaman siswa terhadap bacaan. Bila dikaitkan dengan hasil tes yang dilakukan setelah membaca, kemampuan siswa untuk menjawab pertanyaan dalam tes mengalami peningkatan. Temuan penelitian ini sejalan dengan pendapat Stauffer dalam Harijatiwidjaja (2017, p. 65) bahwa dengan menggunakan strategi DRTA guru bisa memotivasi usaha dan konsentrasi siswa dengan melibatkan mereka secara intelektual serta mendorong mereka merumuskan pertanyaan dan hipotesis, memproses informasi, dan mengevaluasi solusi sementara.

\section{Aktivitas belajar siswa}

Aktivitas belajar siswa dipengaruhi oleh aktivitas mengajar guru. Bila aktivitas mengajar guru baik maka aktivitas belajar siswa akan baik pula. Jika aktivitas mengajar guru terdapat kekurangan maka proses belajar siswa akan bermasalah, hal ini sebagaimana pendapat Sanjaya (2011, p. 3) yang mengatakan bahwa proses pembelajaran dapat dianggap sebagai suatu sistem. Hasil observasi aktivitas belajar siswa siklus I menunjukkan bahwa siswa belum sepenuhnya 
memahami materi pelajaran dengan baik sehingga berpengaruh pada presentase terlaksana aktivitas belajarnya.

Setelah observasi siklus II, aktivitas belajar siswa mengalami peningkatan. Siswa terlihat lebih antusias dalam menjawab pertanyaan yang diberikan oleh guru untuk memprediksi isi bacaan. Setelah melakukan prediksi ini siswa terlihat lebih aktif dalam membaca karena mereka terdorong untuk membuktikan prediksi yang telah mereka buat dengan isi dari bacaan yang sesungguhnya. Temuan ini sesuai dengan pendapat Abidin (2012, p. 81) strategi DRTA diarahkan untuk mencapai tujuan umum agar siswa mampu terlibat langsung dalam pembelajaran, melibatkan proses berpikir dan penglamannya ketika membaca dan merekonstruksi ide-ide pengarang. Keaktifan siswa pada pada siklus II ini tidak terlepas dari aktivitas mengajar guru dalam proses pembelajaran. Hal ini sesuai dengan yang dikemukakan oleh Puspitasari $(2015$, p. 5) bahwa proses pembelajaran pada hakekatnya untuk mengembangkan aktivitas dan kreatifitas peserta didik melalui berbagai interaksi dan pengalaman belajar. Keaktifan belajar siswa merupakan unsur dasar yang penting bagi keberhasilan proses pembelajaran. Dari hasil penelitian, strategi Directed Reading Thinking Activity dapat membuat siswa lebih aktif dan menarik minat mereka pada bahan bacaan karena mereka berperan langsung dalam memprediksi apa yang dipikirkan oleh penulis. Temuan ini sejalan dengan pendapat Kusuma, dkk (2014, p. 3) bahwa melalui strategi DRTA, diharapkan tidak hanya mampu mendorong minat baca siswa melainkan siswa dituntut untuk memberikan prediksi dari sebuah cerita dan mengambil kesimpulan dari cerita yang diberikan oleh guru.

\section{Hasil belajar (kemampuan membaca pemahaman siswa)}

Hasil belajar yang dimaksud dalam penelitian ini adalah kemampuan membaca pemahaman siswa dalam bentuk rata-rata ketuntasan hasil belajar klasikal. Hasil belajar (kemampuan membaca pemahaman siswa) diperoleh melalui tes pada setiap akhir siklus tindakan. Setelah dilaksanakan beberapa kegiatan pembelajaran selama dua siklus. Berdasarkan hasil observasi awal yang dilakukan oleh peneliti sebelum diterapkannya strategi Directed Reading Thinking Activity (DRTA) ditemukan bahwa hasil belajar siswa masih rendah, terlihat pada dokumen guru yang berupa hasil Ulangan Tengah Semester siswa Tahun Ajaran 2018/2019, dari 25 siswa hanya 9 orang siswa (36\%) yang mencapai KKM dengan rata-rata 67,93. Hal ini menunjukkan bahwa lebih dari setengahnya atau 16 siswa (64\%) belum mencapai KKM yang ditentukan. Setelah diterapkan strategi pembelajaran Directed Reading Thinking Activity (DRTA) kemampuan membaca pemahaman siswa pada siklus I mengalami kenaikan dibandingkan dengan kemampuan membaca pemahaman siswa pada observasi awal. Persentase siswa yang tuntas pada siklus I meningkat menjadi $68 \%$ dan siswa yang tidak tuntas mengalami penurunan menjadi $32 \%$ dengan rata-rata sebesar 73,14 . Walaupun mengalami peningkatan, akan tetapi hasil belajar (kemampuan membaca pemahaman siswa) pada siklus I masih tergolong rendah karena belum mencapai indikator keberhasilan yang telah ditetapkan. Maka dari itu, penelitian ini dilanjutkan pada siklus berikutnya yaitu siklus II. Setelah dilakukan perbaikan pada siklus II, kembali terjadi peningkatan pada kemampuan membaca pemahaman siswa. Persentase ketuntasan siswa pada siklus II mencapai $84 \%$ dengan nilai rata-rata sebesar 86,46 . Untuk lebih jelasnya dapat dilihat pada gambar 1 berikut. 


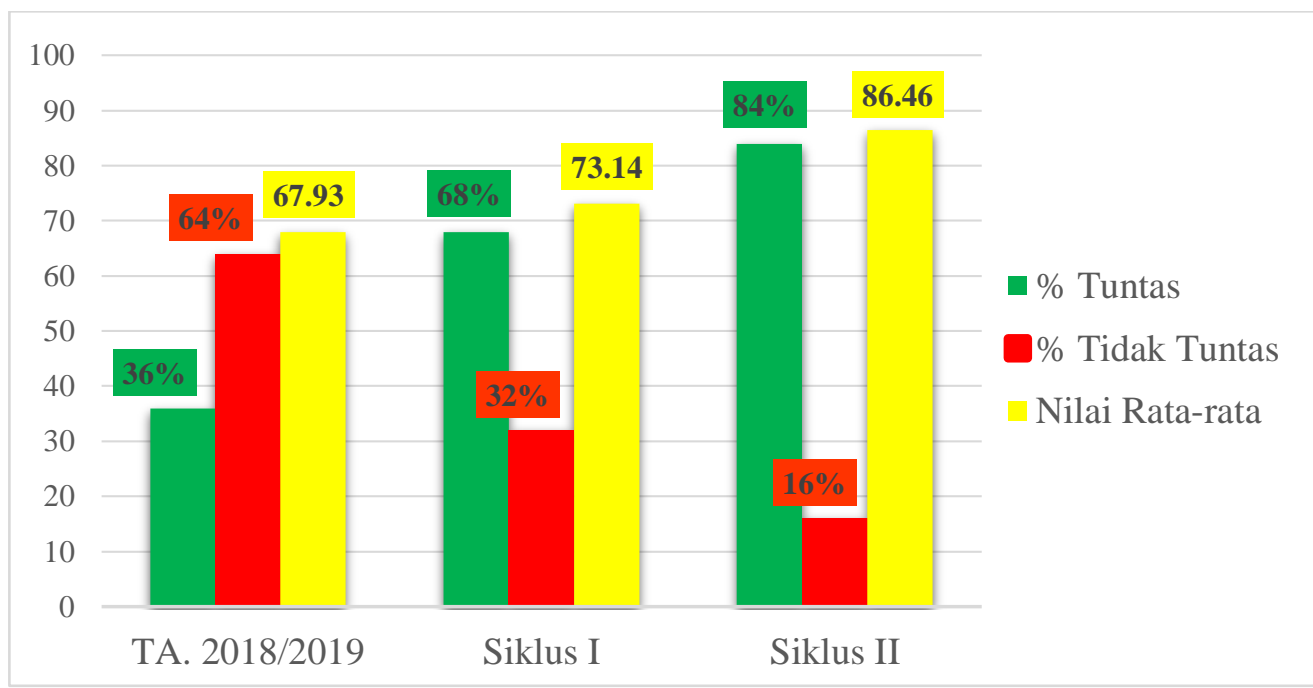

Gambar 1. Peningkatan kemampuan membaca pemahaman siswa

Berdasarkan data hasil evaluasi di atas, menunjukkan bahwa kemampuan membaca pemahaman siswa dapat ditingkatkan melalui strategi pembelajaran Directed Reading Thinking Activity (DRTA). Temuan ini sejalan dengan pendapat yang dikemukakan oleh Harefa, dkk (2019, p. 441) bahwa pembelajaran dengan strategi DRTA membuat siswa menjadi lebih mudah dalam memahami materi pembelajaran, mendorong pemahaman siswa pada bacaan yang telah dibaca.

Hasil evaluasi atau tes yang diberikan kepada siswa pada siklus II menunjukkan bahwa sebagian besar siswa telah mampu membuat prediksi, menemukan ide pokok dari setiap paragraf, menjawab pertanyaan-pertanyaan yang berkaitan dengan isi teks bacaan, dan membuat kesimpulan dari teks bacaan. kemampuan siswa yang demikian menunjukkan bahwa mereka telah memperoleh tujuan dari membaca pemahaman. Sebagaimana yang dikemukakan oleh Jainiyah $(2015$, p. 4) tujuan membaca pemahaman adalah memahami atau menangkap informasi/gagasan penting, mendapatkan ide berdasarkan penjelasan dan contoh implikasi, membuat prediksi, dan menyimpulkan. Sejalan dengan itu Anderson, Pearson, dan Teng dalam Alshumaimeri (2011, p. 187) bahwa "...reading comprehen-sion is viewed as the process of interpreting new information and assimilating this information into memory structures". Artinya membaca pemahaman dilihat sebagai proses membaca dalam menginterprestasikan infor-masi baru dan menggabungkan informasi tersebut ke dalam struktur memori. Keterampilan membaca pemahaman merupakan kemampuan seseorang dalam bekerja secara motorik dan mengoptimalkan fungsi mental yang berhubungan dengan kegiatan kognitif untuk dapat memahami isi bacaan secara detail serta dapat memaknai bacaan dengan cepat dan tepat.

Karena hasil belajar (kemampuan membaca pemahaman siswa) siswa telah tuntas dan komponen dalam skenario pembelajaran telah dilaksanakan maka penelitian ini dihentikan karena hipotesis tindakan telah tercapai yakni jika guru menggunakan strategi Directed Reading Thinking Activity (DRTA) maka kemampuan membaca pemahaman siswa kelas V-B SD Negeri 24 Kendari meningkat. Temuan tersebut sesuai dengan pendapat Walker dalam Muhammad Fatih (2019, p. 29) bahwa strategi Directed Reading Thinking Activity (DRTA) merupakan instruksi dalam pembelajaran membaca dengan memprediksi apa yang penulis pikirkan, mengkonfirmasi atau merevisi prediksi dan mengkolaborasi pendapat sehingga pemahaman mereka akan meningkat.

\section{Simpulan}

Penerapan strategi pembelajaran Directed Reading Thinking Activity (DRTA) dapat meningkatkan kemampuan membaca pemahaman siswa kelas V-B SD Negeri 24 Kendari, pada siklus I persentase ketuntasan secara klasikal 68\% dengan nilai rata-rata 73,14 meningkat pada siklus II persentase ketuntasan $84 \%$ dengan nilai rata-rata 86,46 . Pengamatan aktivitas mengajar guru pada siklus I pertemuan pertama sebesar $56 \%$ dan pertemuan kedua sebesar $69 \%$. Sedangkan pada siklus II pertemuan pertama sebesar $88 \%$ dan pertemuan kedua sebesar $100 \%$. Pengamatan aktivitas belajar siswa pada siklus I pertemuan pertama adalah sebesar $56 \%$ dan pertemuan kedua 
sebesar $69 \%$. Sedangkan pada siklus II pertemuan pertama sebesar $88 \%$ dan pertemuan kedua sebesar $100 \%$.

\section{Daftar Pustaka}

Abidin, Y. (2012). Pembelajaran Membaca Berbasis Pendidikan Karakter. Bandung: PT Refika Aditama.

Alshumaimeri, Yousif. (2011). The Effects of Reading Method on the Comprehension Performance of Saudi EFL Students. International Electronic Journal of Elementary Education, 2011, 4(1), 185-195. https://www.researchgate.net/publication/285941252_The_effects_of_reading_method_o n_the_comprehension_performance_of_Saudi_EFL_students

Aningsih, \& Jayanty, Icy Putri. (2017). Upaya Meningkakan Keterampilan Membaca Pemahaman Siswa Melalui Strategi Directed Reading Thingking Activity (DRTA) di Kelas III SD Bani Saleh 2 Bekasi Pada Pelajaran Bahasa Indonesia. Pedagogik, V(2), 22-29. http://jurnal.unismabekasi.ac.id/index.php/pedagogik/article/view/446

Apriliana, A. C., \& Berlianti, R. P. (2018). Upaya Meningkatkan Keterampilan Membaca Pemahaman Melalui Strategi Directed Reading Thingking Activity (DRTA) Pada Siswa Kelas V SDN Gudangkopi II Kecamatan Sumedang Utara Kabupaten Sumedang Tahun Pelajaran 2015/1016. Jurnal Ilmiah Pendidikan Dasar, III(1), 69-83. https://journal.unpas.ac.id/index.php/pendas/article/view/1027

Arikunto, S., Suhardjono., \& Supardi. (2015). Penelitian Tindakan Kelas. Jakarta: Bumi Aksara.

Fatih, Mohamad. (2019). Peningkatan Membaca Pemahaman melalui Strategi Direct Reading Thingking Activities (DRTA) Siswa Kelas VA SDN Bendogerit 1 Kota Blitar. Jurnal Pendidikan, $3(1)$, 28-34. http://journal.unublitar.ac.id/pendidikan/index.php/Riset_Konseptual/article/view/99

Harefa, F. T., Sukma, E., \& Desyandri. (2019). Pengaruh Penggunaan Strategi Directed Reading Thinking Activity (DRTA) Terhadap Kemampuan Membaca Pemahaman Siswa Kelas V Sekolah Dasar Negeri 29 Purus. Jurnal Basicedu, 3(2), 435-442. https://jbasic.org/index.php/basicedu/article/view/24

Harijatiwidjaja, Nantje. 2017. The Implementation of DRTA Cooperative Model In Reading Explanation Text Comprehension. Metalingua, 15(1), 63-72. https://media.neliti.com/media/publications/193323-EN-none.pdf

Indarti, Titik. 2008. Penelitian Tindakan Kelas (PTK) dan Penulisan Karya Ilmiah: Prinsip-prinsip Dasar, Langkah-langkah dan Implementasinya. Surabaya: FBS Universitas Negeri Surabaya.

Jainiyah, Siti. (2015). Penerapan Strategi Direct Reading Thinking Activity (DRTA) Untuk Meningkatkan Keterampilan Membaca Pemahaman Tema Berbagai Pekerjaan Siswa Kelas Sekolah Dasar. JPGSD, 3(1), 1-7. https://media.neliti.com/media/publications/253582-penerapan-strategi-direct-readingthinki-64f22901.pdf

Kusuma, I. B. I., Japa, I. G. N., Sumantri, M. (2014). Pengaruh Strategi Direct Reading Thinking Activty (DRTA) Terhadap Keterampilan Membaca Pemahaman Siswa. Ejournal Mimbar PGSD, 2(1), 1-10. https://ejournal.undiksha.ac.id/index.php/JJPGSD/article/view/3806

Murti. (2019). Peningkatan Keterampilan Membaca Pemahaman Melalui Penggunaan Strategi Directid Reading Thinking Activity (DRTA) Pada Siswa Kelas V Negeri 8 Bengkalis Kecamatan Bengkalis Kabupaten. Jurnal Pendidikan Tambusai, 3(1), 180-194. https://doi.org/10.31004/jptam.v3i1.213 
Jurnal Ilmiah Pembelajaran Sekolah Dasar

Volume 2 Nomor 1 - Februari 2020, e-ISSN 2656-0402

Available online at:http://ojs.uho.ac.id/index.php/jipsd

Puspitasari, D. (2015). Peningkatan Kemampuan Membaca Pemahaman Cerita Pendek Melalui Penerapan Strategi Directed Reading Thinking Activity (DRTA) Pada Siswa Kelas V SD Negeri 1 Rabak Kabupaten Purbalingga. Metafora, 2(1), 1-18. http://jurnalnasional.ump.ac.id/index.php/METAFORA/article/view/288

Rahim, F. (2009). Pengajaran Membaca di Sekolah Dasar. Padang: Bumi Aksara.

Sanjaya, W. (2011). Penelitian Tindakan Kelas. Jakarta: Kencana Prenada Media Group. 